
Yil 15
Güz 2017
Sayı 23
Ss. 221-246

Geliş Tarihi: 05.10.2017

Kabul Tarihi: 17.10.2017

\title{
Avustralyalı Gazeteci Keith Arthur Murdoch'ın Çanakkale Cephesine Dair Raporunun Analizi
}

\author{
Fikrettin YAVUZ* \\ Murat TOMAN**
}

\begin{abstract}
$\ddot{O}_{z}$
Gazeteciler bilhassa savaş muhabirleri Birinci Dünya Savaşı'nın önemli cephelerinden biri olan Çanakkale'deki gelişmeleri gerek gazete yazıları ve mektupları gerekse raporlarıla Dünya kamuoyuna taşımışlardır. Bu gazetecilerden biri olan Avustralyal Keith Arthur Murdoch'in kaleme aldiğl ve Gelibolu Mektubu olarak da bilenen raporu, sonuçları itibariyle bilhassa İtilaf Devletleri açısından tarihi bir değere sahiptir. Bu doğrultuda raporun Itilaf Devletleri'nin Çanakkale cephesini terk etmelerinde ve özellikle Anzak efsanesinin oluşmasında ciddi payı vardır. Raporu incelendiğinde başarısızlı̆̆ın sorumlusu olarak gördüğ̈̈ İngiliz kurmay sınıfinı tasvir ederken acınası, başarısız, niteliksiz gibi tabirler kullanan Murdoch'ın, cephenin kapatılmasının zeminini hazırladiğ söylenebilir. Bununla birlikte metnin tamamında Anzak askerleriyle ilgili en küçük bir olumsuz yaklaşım sergilemediği gibi askerlere yönelik şanlı askerlerimiz ve kahramanlarımı şeklinde ifadeler kullanarak bu efsanenin temellerini atmıştır.
\end{abstract}

Bu çalışmanın amacı Murdoch'ın yukarıda bahsi geçen iki husus hakkındaki görüşlerinin yanı sıra onlar kadar yer vermemiş olsa da Türk askerine dair görüşlerinin analiz edilmesidir. Nitekim Murdoch, Türk askeri hakkında son derece müspet sözler sarf etmekte, insaniyet ve cesaret kelimelerini Türk kelimesi ile birlikte kullanmaktadır.

Anahtar Kelimeler: Itilaf Devletleri, Çanakkale Savaşı, Gelibolu, Gazeteci, Rapor

\footnotetext{
* Fikrettin YAVUZ, Doç. Dr., Sakarya Üniversitesi, Fen-Edebiyat Fakültesi, Tarih Bölümü, Esentepe Kampüsü, 54187 Sakarya Türkiye, fyavuz@sakarya.edu.tr

** Murat TOMAN, Sakarya Üniversitesi, Sosyal Bilimler Enstitüsü, Tarih Bilim Dalı, Doktora Öğrencisi.
} 


\title{
Analysis of the Report on Dardanelles Campaign by Australian Journalist Keith Arthur Murdoch
}

\begin{abstract}
Journalists, especially war correspondents brought the developments of the Dardanelles Campaign, one of the important fronts of the First World War, with both their articles, letters, and reports to the world public opinion. One of the journalists' report, known also as the Gallipoli Letter, of Keith Arthur Murdoch of Australia, has a historical value for the Allied Powers especially in terms of its results. In this respect, it is thought that the report has a considerable share both in the Allied Powers' abandonment of the Dardanelles, and especially in the formation of the Anzac legend. When reviewing the report, it might be said that Murdoch, who uses phrases such as pitiful, unsuccessful, unqualified while describing the English army staff which he deemed responsible for the failure, has laid the groundwork for withdrawing the Dardanelles. Besides, not showing the least negative approach to their soldiers in the report, he has laid the foundations of the Anzac legend by using expressions like our glorious soldiers and heroes.

The aim of this study is to analyze Murdoch's opinion on Turks, whom he did not give much place compared to the two issues mentioned above. In fact, he both makes very positive words about the Turkish army and uses the words, humanity and courage together with the word Turk.
\end{abstract}

Key Words: The Allied Powers, Dardanelles Campaign, Gallipoli, Journalist, Report 


\section{Giriş}

İnsanlık tarihinin eski devirlerinden beri Boğazlar stratejik önemleri dolayısıyla büyük güçlerin her daim ilgisini çekmiştir. Dünya'nın tecrübe ettiği ilk büyük savaş olan Birinci Cihan Harbi’nde de durum değişmemiştir. İtilaf Devletleri sonuçları itibariyle savaşın gidişatına son derece büyük bir etki yapmış olan ve aynı zamanda muazzam bir vuruşmanın yaşandığı Çanakkale Cephesi'ni açmışlardı. İngiltere'nin başını çektiği İtilaf grubu, başlangıçta Çanakkale'yi kolay bir şekilde geçerek İstanbul'u işgal ve müttefikleri Rusya'ya yardım edebileceklerini düşünmüştü. Bu amaçla yapılan plan, ilk etapta kara birliği desteği sağlanamadığı için İtilaf donanmasının kendi olanaklarıyla Çanakkale boğazını zorlayıp geçmesi şeklindeydi ${ }^{1}$. Ancak İngiltere Savaş Bakanlığı'na taarruzla ilgili gönderilen ilk raporlarda, donanmanın tek başına boğazdan geçmesinin mümkün olmadığı, ne pahasına olursa olsun ordunun işe karıştırılması gerektiği bilgisi verildi². Bu düşünceler doğru çıktı ve 18 Mart 1915 'te denizde alınan büyük hezimetten sonra, İtilaf filolarının geçişine engel olduğu düşünülen bataryaları etkisiz hale getirmek amacıyla kara savaşlarına girişildi. Yaklaşık 13-14 ay süren deniz ve kara harekâtı sonucunda İtilaf Devletleri Ocak 1916'da cepheyi terk etme kararı almak zorunda bırakılmışlardı ${ }^{3}$. Bu durum İtilaf Devletleri açısından adeta bir fiyasko olduğu gibi özellikle İngilizlerin yenilmez armada imajını da zedelemiş olmalıdır. Bir yılı aşkın bu süre zarfında Çanakkale'de meydana gelen hadiseler, doğal olarak kamuoyu oluşturmada ön planda olan gazete ve dergiler tarafindan yakinen takip edildi ${ }^{4}$.

$\mathrm{Bu}$ çerçevede Çanakkale Cephesi’ni yerli ve yabancı birçok gazeteci ziyaret etmiş, özellikle savaş muhabirleri gelişmeleri kendi kamuoylarına aktarmışlardır. Cepheyi ziyaret eden bu gazetecilerin sayısı hayli fazla olmakla birlikte net bir rakam vermek mümkün değildir. İzin alarak cepheye gelenlerin sayısının otuzun üzerinde

1 Çanakkale Cephesi'nin açılış nedenleri hakkındaki değerlendirme ve cephenin açılması konusunda bkz. Figen Atabey, Çanakkale Muharebelerinin Deniz Cephesi, Türk Tarih Kurumu, Ankara 2014, s. 31-43; S. Murat Hatip, "Birinci Dünya Harbi Çanakkale Savaşları’na Genel Bakış ve Az Bilinenler Çanakkale Savaşı Denizde mi Kazanıldı?”, Çanakkale Araştırmaları Türk Yıllı̆̆ , Yı1: 13, Bahar 2015, Say1: 18, s. 167-169.

2 Alan Moorehead, Çanakkale Geçilmez, Çev. Güney Salman, Milliyet Yay., İstanbul 1972, s. 103.

3 Savaş süreci ve sonuçlanması hakkında geniş bilgi için bkz. Genelkurmay Harp Tarihi Başkanlığı,

Birinci Dünya Harbi’nde Türk Harbi, Çanakkale Cephesi Harekâtı, V. Cilt, 1. Kitap, Genelkurmay Basımevi, Ankara, 1993; C. F. Aspinall-Oglander, Büyük Harbin Tarihi Çanakkale Gelibolu Askeri Harekâtı, Cilt. 1-2, (haz. Metin Martı), Arma Yayınları İstanbul 2005.

4 Bu konuda Türkçe literatürde birçok çalışma yapılmıştır. Örneğin bkz. Yücel Özkaya, “Türk ve Dünya Basınında Çanakkale Savaşları”, Atatürk Araştırma Merkezi Dergisi XII/34, Ankara 1996, s. 295 313; Recep Karacakaya, “Çanakkale Savaşları'nın Amerikan Basınındaki Yansımaları”, Yeni Türkiye Çanakkale Özel Sayısı, Y11 21, Sayı 65, Ocak-Şubat 2015, s. 1357-136; Fehim Kuruloğlu, "Sydney Morning Herald Gazetesi'ne Göre Gelibolu'da Savaş ve Barış, Peace and War in Gallipoli According to Sydney Morning Herald", III. International Gallipoli Symposium, 20-25 Nisan 2012, İstanbul 2013, s. 345-361; Zeynep İskefiyeli, "Savaş ve Propaganda: Resimli İngiliz Dergilerinde Çanakkale Cephesi”, Yeni Türkiye Çanakkale Özel Sayısı, Y11 21, Sayı 65, Ocak-Şubat 2015, s. 1461- 1473. 
olduğu söylenmekte ise de izin almadan gelenlerle bu sayının daha yüksek rakamlara ulaştığını kabul edebiliriz 5 . Cepheye giden savaş muhabiri ve gazetecilerin bazıları gönderdikleri telgraf ve haberlerle o sırada kendi ülkelerinde kamuoyu oluştururken, bu kişilerin yazdıkları Çanakkale cephesindeki gelişmeleri anlamada tarihçilerin başvurdukları önemli kaynaklar arasında sayılmaktadır. Bu noktadan bakıldığında bazı gazetecilerin ön plana çıktığını söylememiz gerekir. Bunlar arasında Türk kamuoyunun yakından tanıdığı, eserleri Türkçeye tercüme edilmiş, hakkında makaleler kaleme alınmış olan Ellis Ashmead-Bartlett şüphesiz en dikkat çekenidir ${ }^{6}$. Son yıllarda Çanakkale cephesine gelmiş olan gazetecilerin kaleme aldıkları eserlerin Türkçeye tercümelerinde bir ivme olduğu da dikkati çekmektedir. Bu noktada, biri savaş muhabiri Paul Schweder ve diğeri gazeteci ve seyyah Rudolf Zabel, iki Alman gazeteci ile Fransız Savaş Muhabiri Gabriel Domergue adlı kişilerin Çanakkale hakkındaki kitapları Türk okuyucularına sunulan eserlerdendir ${ }^{7}$. Bununla birlikte bu türlü eserler hakkında akademik makalelerin de kaleme alındığını görüyoruz. Söz gelimi Amerikalı bir gazeteci olan George Abel Schreiner'in "From Berlin to Bagdad" adlı hat1ratında Çanakkale Deniz ve Kara Savaşları hakkında kaydetmiş olduğu değerlendirmeleri itinalı bir şekilde ele alınmıştır ${ }^{8}$. Bunların yanı sıra yazdıkları henüz Türkçeye tercüme edilmemiş veya hakkında akademik çalışma yapılmamış onlarca gazeteci ve savaş muhabirinden de söz etmek mümkündür. Bu bağlamda İtilaf Devletleri'nin Çanakkale cephesini terk etmelerinde ve özellikle Anzak efsanesinin oluşmasında ciddi payı olduğu düşünülen Avustralyalı bir gazetecinin hazırladığı raporun ele alınmasının önem arz ettiği kanaatindeyiz. Bu gazeteci, kurduğu şirketi daha sonra büyük bir medya imparatorluğuna dönüşecek olan Keith Arthur Murdoch'tan başkası değildir. Raporun detaylarına değinmeden önce Çanakkale Cephesi ve Türklere yönelik yakla-

5 Cepheye giden gerek yerli gerekse yabancı gazetecilerin sayısı hakkında Anadolu Ajansı'na mülakat veren Prof. Dr. Selda Kılıç'ın değerlendirmeleri için bkz. http://aa.com.tr/tr/turkiye/yabancigazeteciler-canakkale-savaslarini-anlatti/58287 (11. 03. 2017).

6 Bartlett'in Türkçeye tercüme edilmiş çalışmaları şunlardır: Ellis Ashmead Bartlett, Çanakkale Gerçeği (Çev. Yüzbaşı Rahmi; Yay. Haz. Muzaffer Albayrak), Yeditepe Yay., İstanbul 2007. Ellis Ashmead Bartlett, Sansürsüz Çanakkale, Çev. Arzu Tüfekçi, İz Yayıncılık, İstanbul 2015.

7 Paul Schweder, Çanakkale Cephesinde Türklerin Genel Karargahında, Çev. Eşref Bengi Özbilen, Yeditepe Yayınevi, İstanbul 2012. Rudolf Zabel, İstanbul İçin Savaş Bir Alman Gazetecinin Çanakkale Savaşı Anıları, Çev. Rüstem Aslan, Cümle Yayınları, Ankara 2015; Gabriel Domergue, Çanakkale Yolunda, Çev. Ömer Faruk Turan, Babıali Kültür Yayıncılığı, İstanbul 2007.

8 Mustafa Göleç, “Amerikalı Bir Gazetecinin Gözüyle Çanakkale Deniz ve Kara Savaşları: George Abel Schreiner ve Çanakkale Günlükleri”, Çanakkale Araştırmaları Türk Yıllı̆̆l, Yı1: 13, Bahar 2015, Sayı 18, s. 593-635.

9 Raporun orijinali Avustralya Ulusal Kütüphanesi'nde bulunmaktadır. Sir Keith Arthur Murdoch (18851952) Gallipoli Letter from Keith Arthur Murdoch to Andrew Fisher 1915, Manuscripts Collection, MS 2823 Papers of Sir Keith Arthur Murdoch, 1908-1967. nla.ms-ms2823-2. Jack Thomson'un önsözünü, Michael McKernan'ın girişini yazdığı 2010 yılında Avustralya'da yayınlanan Gallipoli Letter adlı kitapta mektubun tıpkı basımı da yapılmıştır. Keith Murdoch, Gallipoli Letter, Allen \& Unvin, Australia 2010. 
Şımını daha doğru bir şekilde anlamak adına bu gazeteciyi kısaca tanıtmanın faydalı olacağı kanaatindeyiz.

\section{Keith Arthur Murdoch Kimdir?}

19. yüzyılın sonlarından günümüze, birçok gazetecinin, yaptığı haberler ve yayınladıkları fotoğraflarla savaşların kaderini değiştirdiklerinden bahsedilmektedir. Bu isimlerin başında gelen ve gazetecilik tarihine adını altın harfler ile yazdıran Keith Arthur Murdoch, Melbourne'de 1885 yılında dünyaya geldi ${ }^{10}$. İlk gazetecilik deneyimine, stenografi konusundaki yeteneğinden dolayı, daha 18 yaşındayken dönemin ünlü gazetecisi David Syme sayesinde 1903 yılında başladı ${ }^{11}$. The Age isimli gazetenin banliyö muhabiri olarak Melbourne'un Malvern kasabasında çalışmaya başlayan Murdoch, başarılı bir muhabir olarak gazetesinin satışını yaşadığ 1 bölgede arttırdı. Yaklaşık beş yıl boyunca, yerel bir muhabir olarak çalışan Murdoch, 1908 yılında, biriktirdiği 500 pound civarında para ile Londra'nın yolunu tuttu' ${ }^{12}$. İngiltere'nin başkentinde geçirdiği 18 ay boyunca büyük sıkıntılar çekti. Talihi, Londra'ya ziyarete gelen, dönemin Avustralya Başbakanı Alfred Deakin ile tanışmasıyla, döndü. Deakin sayesinde Lord Alfred Milner ile tanıştı. Milner Secret Elite isimli bir örgütün lideri ve imparatorluk işleri konusunda söz sahibi, daha doğru bir ifadeyle sömürgelerden sorumlu bir kişiydi. Milner, Birinci Dünya Savaşı sırasında, Çanakkale Seferi'nin yapılmasına muhalefet eden grubun içerisinde yer almıştı. Savaşın son yedi ayında, Britanya'da yönetimi ele alan David Lloyd George tarafından Savaş Bakanı olarak atand1. Ne tesadüftür ki, daha sonra Murdoch'ın kaleme aldığı mektup, Lloyd George tarafından ele geçirilecek ve bu mektup Britanya'da hükümet değişikliğini tetikleyecek unsurlardan biri olacakt ${ }^{13}$.

Kasım 1909 tarihinde, ABD üzerinden Avustralya'ya dönüş yapan Murdoch, The Age gazetesinde yeniden işe başladı. Yaklaşık iki yıl boyunca haftada 4 pound para kazanan Murdoch, bu süreç içerisinde çocukluğundan beri muzdarip olduğu kekemelik sorununun üstesinden gelmeyi başardı. Daha akıcı ve seri konuşmaya başlayan Murdoch, 1912 yılında The Evening Sun isimli gazetenin İngiliz Milletler Topluluğu Parlamentosu muhabiri oldu. Bu görevi sayesinde başta dönemin Başba-

10 Geoffrey Serle, "Murdoch, Sir Keith Arthur (1885-1952)", Australian Dictionary of Biography, vol. 10, 1986, s. 622-627. Murdoch yedi çocuklu dindar bir ailenin ikinci çocuğudur. Babası, Patrick Murdoch, Presbiteryan Kilisesi papazıdır. Keith yarı kırsal bir yerleşim yeri olarak tanımlanan Camberwell'de büyümüştür. Gelecekte büyük bir medya baronu olacak olan Murdoch kekeme olduğu için oldukça sıkıntılı bir çocukluk geçirmiştir. Sırasıyla önce Camberwell State okulunda ve çok iyi bir okul olduğu belirtilen Camberwell Gramer okulunda eğitimini tamamlayan Murdoch, üniversite okumak yerine gazetecilik yapmaya karar vermiştir. Bu verdiği karar her ne kadar ailesini hayal kırıklığına uğratsa ve endişelendirse de, ailesi kekemelik sorunu çeken çocuklarının kararını desteklemişti. Bruce Page and Elaine Porter, The Murdoch Archipelago. London: Simon \& Schuster, 2003, s. 22.

11 Page and Porter, The Murdoch Archipelago, s. 23.

12 Serle, "Murdoch, Sir Keith Arthur (1885-1952)", s. 622-623.

13 Page and Porter, The Murdoch Archipelago, s. 26. 
kanı Andrew Fisher, babasının arkadaşı ve 1915 yılından sonra Başbakan olacak olan Billy Hughes ve 1914-1921 yılları arasında Savunma Bakanlığı yapan Sir George Pearce olmak üzere birçok politikacı ile yakınlık kurmayı başard ${ }^{14}$. Tüm bu yüksek düzeyde ilişkileri geliştirebilmesinde Lord Alfred Milner'ın katkısı yadsınamaz derecede önemliydi. Bundan öte, Murdoch, Milner ile tanışmasının kendisine sağladığı avantajlar sayesinde, 1910 yılında Avustralya Gazeteciler Derneği’nin kurucu üyeleri arasinda yer ald $\mathbf{1}^{15}$.

Bütün bu bağlantılar sayesinde Murdoch kariyer basamaklarını hızla çıkmaya başladı. 1914 yılının Temmuz ayında, The Evening Sun gazetesinin de sahibi olan Sir Hugh Denison tarafından, yıllık 800 dolar maaş teklifi ile Sydney World isimli gazetenin editörü olarak görevlendirildi. Eylül ayı geldiğinde, Birinci Dünya Savaşı'nı izlemesi için, Avustralyalı Gazeteciler Derneği, ünlü tarihçi ve savaş muhabiri olan Charles Bean'i bir oy fark ile Avustralya savaş muhabiri olarak seçti. Bu sonuç Murdoch için üzücüydü fakat savaş muhabiri olabilmek için çok fazla beklemeyecekti. Nihayetinden bu hayal kırıklığını telafi etmek için 13 Temmuz 1915 tarihinde dönemin Başbakanı Fischer ve Savunma Bakanı Pearce, Murdoch'1 Avustralya ordu mensuplarının yaşamakta olduğu posta hizmetleri ile alakalı sorunları çözmesi için The Times gazetesinin United Cable Service editörlüğüne atad $1^{16}$. Böylece Murdoch'ın kısa ve fakat sonuçları itibariyle çok önemli olan Çanakkale macerası da başlamış oldu.

\section{Murdoch'ın Gelibolu Ziyareti}

1915 yılında, Murdoch’ın seyahatinin önünü açan ve aynı zamanda savaşın kaderini değiştiren bir kritik atama yapıldı. Avustralyalı savaş muhabiri Charles Bean, Çanakkale cephesinden alınarak Londra'da United Cable Service of the Sun and Melbourne Herald isimli iletişim şirketinin yönetici editörü görevine getirildi. Bu atamaya Başbakan Fischer ve Savunma Bakanı Pearce, cepheden ilk elden ve güvenilir bilgi elde edemeyeceklerini düşünerek karşı çıkmıştı ama askeri sansür nedeniyle zaten sağlıklı bilgi alamıyorlardı. Bu sorunu aşmak için Avustralya hükümeti, Murdoch'1 Avustralyalı askerlerin yaşadığı posta hizmetleri sorununu çözmek için görevlendirdi. $\mathrm{O}$ ise, posta hizmetleri ile ilgili sorunları bizzat sahada görerek çözmek için önce Kahire’ye gitti. Gelibolu’ya gidebilmek için de Gelibolu Seferi Komutanı Sir Ian Ha-

14 Serle, "Murdoch, Sir Keith Arthur (1885-1952)", s. 623, Fitzhardinge, L. F. "Hughes, William Morris (Billy) (1862-1952)", Australian Dictonary of Biography, volume. 9, (MUP), 1983, http://adb.anu. edu.au/biography/hughes-william-morris-billy-6761 (12.04.2017), B. Beddie, "Pearce, Sir George Foster (1870-1952)", Australian Dictionary of Biography, volume. 11, (MUP), 1988, http://adb.anu. edu.au/biography/pearce-sir-george-foster-7996 (12.04.2017).

15 Jim Mcgregor and Gerry Docherty, "Gallipoli 18: Keith Murdoch And The Great Witch-Hunt", First World War Hidden History, https://firstworldwarhiddenhistory.wordpress.com/2015/04/22/gallipoli18-keith-murdoch-and-the-great-witch-hunt/ (12. 04. 2014).

16 Jim Mcgregor and Gerry Docherty, "Gallipoli 18: Keith Murdoch And The Great Witch-Hunt", Desmond Zwar, In Search Of Keith Murdoch, London: Macmillan 1980, s. 20. 
milton ile iletişime geçti. 17 Ağustos 1915 'te Hamilton'a bir mektup göndererek şu şekilde izin talebinde bulundu:

"Sadece yarl resmi bir kimlikle orada bulunmak isterim. Böylelikle temsil etmekte olduğum Avustralya ve Londra gazetelerinde, oradaki sansür izlenimini de silmiş olacağım. Fakat hiç şüphesiz göstereceğiniz her şarta içten bağlı kalacağım... Zât-ı âlilerinizle Melbourne şehir kulübünde tanışmış olmak şerefine nail olduğumu ve ziyaretinizi Sidney Sun ve Melbourne gazetelerinde yazmış olduğumu eklememe izin vermenizi istirham ederim. Yine arz etmek isterim ki bir Avustralyalı olarak ordumuzun bulunduğu kutsal Gelibolu sahillerini görmek için derin bir istek duymaktayım" "'7.

İzin talebinde Hamilton kendisine, cepheye gelme iznini sansür ile alakalı kurallara uyma şartı ile verdi. Murdoch sansür kurallarına uyacağını ifade eden resmi deklarasyonu imzaladı ve Gelibolu cephesini ziyaret etme iznini Ağustos ayında elde etti $^{18}$.

Murdoch'ın tarihi ziyareti dört gün sürmüştür. Vardığg 2 Eylül'de yazdıklarını karargâhta bulunan sansür kuruluna göstereceğine yönelik savaş muhabirleri beyannamesini imzaladı. Müteakiben Hamilton'un, istediği yeri gidip görmesi noktasındaki yardım teklifini reddettikten sonra ise Anzak askerlerinin olduğu köprübaşına kısa bir ziyaret yaptı. Ardından İmroz'a (Gökçeada) döndü ve basın kampına yerleşti. Hamilton'un karargahının hemen yakınında bir zeytinlik içerisindeki bu kampta Daily Mail'den G. Ward Price ve Daily Telegraph'tan Ellis Ashmead-Bartlett gibi devrin ünlü savaş muhabirleri vardı. Murdoch'ın tarihi misyonu işte burada Bartlett ile tanışmasıyla başlad $1^{19}$. Burada bulunduğu sırada Avustralyalı savaş muhabiri Charles Bean ve diğer iki Avustralyalı gazeteciyle de görüştü.

Murdoch ilk anda burada gördüklerinden ve askerlerden duyduklarından dolayı dehşete düşmüş, askerlerin genel durumlarının son derece kötü olduğuna şahit olmuştu. Görüştüğü askerler de genel karargâhı ciddi manada eleştiriyorlard1 ${ }^{20}$. Murdoch'ın Anzakları ziyaret etme müsaadesi aldığını ve kamplarında kaldığını belirten Bartlett, onun ordunun durumu ve muhtemel bir kış savaşından son derece endişeli olduğunu, Avustralyalıların en çok bundan çekindiklerini, siperlerin çoğunun kesinlikle savunulmaz durumda olacağını kendisine söylediğini dile getirmektedir. Ona hak veren Bartlett'e söylediğine göre, eğer bir şeyler yapılmazsa, birisi anavatanda gerçeklerin neler olduğunu duyurmazsa son derece olumsuz bir durum ortaya çıkacaktı. Murdoch, kendisi kısa süreliğine orada olduğundan ve sadece Anzaklarla görüştüğünden, söy-

17 Moorehead, Çanakkale Geçilmez, s. 410-411.

18 Sydney Morning Herald, "How one man's Report on Gallipoli Changed The Course of War", 18 November 1968, s. 8.

19 Phillip Knightley, The First Casualty - From Crimea to Vietnam: The War Correspondent as Hero, Propagandist, and Myth Maker, New York and London 1975, s. 101, Moorehead, Çanakkale Geçilmez, s. 411.

20 Moorehead, Çanakkale Geçilmez, s. 411. 
leyeceklerinin yetkililer nezdinde fazlaca etkili olmayacağını, bu nedenle Bartlett'ten bir rapor hazırlamasını istedi. Bartlett de uzun süredir İngiltere'ye dönmeyi düşünse de izin alamıyordu. Murdoch'ın bu teklifini reddettiği takdirde, İngiliz kamuoyuna savaşın gerçeklerini aktarma noktasında son şansını da kaybedeceğini düşünüyordu ${ }^{21}$. Çünkü adaya ulaştığı ilk günden itibaren İmroz'da ciddi sıkıntılar yaşıyor, özellikle sansürün başında olan William Maxwell'ın İngiliz kamuoyuna gerçekten neler olduğunu aktarma noktasındaki engelleriyle karşılaşıyordu. Hamilton'un talimatı gereği Maxwell, resmi telgraflar Londra'ya erişmeden Bartlett'in hiçbir mesajının İngiltere'ye ulaşmasına müsaade edilmiyordu ${ }^{22}$. Murdoch'ın biyografisini kaleme alan Desmond Zwar ise böyle bir mektubun gönderilmesi fikrinin Bartlett'ten geldiğini ifade etmekte, Hamilton'un savaşı idaresinden nefret ettiği için Murdoch'tan, yazacağı mühürlü bir mektubu Londra'ya varınca postaya vermesini istediğini kaydetmektedir ${ }^{23}$. Mektubun gönderilme fikrinin kimden geldiği net olmasa da açık olan Bartlett'in, tüm bu engellerin ortadan kaldırılmasında ve İngiliz kamuoyunun gerçeklerden haberdar olmasında, Murdoch'1 son umut olarak görmüş olduğudur.

Keith Murdoch Marsilya’ya gidecek olan gemiyi beklerken, Bartlett İngiltere Başbakanı Asquith'e hitaben yazdığı uzun mektubu kaleme aldı ${ }^{24}$. Mektubun yanısıra, Bartlett'in ifadesiyle Murdoch'a Gelibolu'daki orduyu kurtarabilecek bir kampanyayı düzenleyebilecek kimselere yazılmış tavsiye mektupları vermişti. Bununla birlikte Bartlett, Murdoch'a, çalıştığı Daily Telegraph gazetesinin sahibi Harry Lawson'a gitmesi ve kendisini geri çağırtmasını söylemesini istedi. Murdoch'ın yola çıkmasının ardından ilk kez rahatladığını dile getiren Bartlett, bu iş esnasında Murdoch'ın başına bir şey gelirse veya yetkililer onun uyarılarına kulak asmazlarsa hemen istifa edecek, Londra'ya giderek ona katılacaktı ${ }^{25}$.

Gelibolu'dan ayrıldıktan sonra, Marsilya'ya kadar gizlice raporu taşımayı başaran Murdoch, taşıdığı rapordan haberi olan Guardian'ın savaş muhabiri Henry Nevison’un durumu İngilizlere bildirmesi neticesinde, raporu Britanyalı subaylara teslim etmek zorunda kald $1^{26}$. Fransız askerleri tarafindan tutuklanmasina kızan Murdoch, gözlemlerini, Bartlett'in raporundaki ve diğer gazetecilerden aldığı bilgileri harmanlayarak, Londra'ya varmadan evvel ünlü 8000 kelimelik mektubunu yazdı. 23 Eylül 1915 tarihinde de Avustralya Başbakanı Fisher'a bu mektubu yollamayı başardı ${ }^{27}$.

Kimi iddialara göre, Murdoch, gizli bir görev ile yani, savaşın ne durumda olduğunu görmek için, bizzat Avustralya Başbakanı ve Savunma Bakanı tarafından görev-

21 Ellis Ashmead Bartlett, The Uncensored Dardanelles, Hutchinson and Co. London 1928, s. 239.

22 Knightley, The First Casualty, s. 101.

23 Zwar, In Search Of Keith Murdoch, s. 40-41.

24 Mektubun orijinal metni için bkz. Bartlett, The Uncensored Dardanelles, s. 240-243.

25 Bartlett, The Uncensored Dardanelles, s. 244, Moorehead, Çanakkale Geçilmez, s. 412.

26 Knightley, The First Casualty, s. 101.

27 Serle, "Murdoch, Sir Keith Arthur (1885-1952)", s. 623-624. 
lendirilmişti. Askerlerin yaşadığı mektup gönderememe sorunu için bir gazetecinin görevlendirilmesinin biraz kuşku verici olduğu düşünülüyordu. General Ian Hamilton bu konuda kendisinin de kuşkulandığını, daha sonra yazdığ 1 ve 1920 yılında yayınlanan günlüğünde dile getirmektedir ${ }^{28}$. Fakat komutan için artık çok geç olmuştu zira, Murdoch, Hamilton'un kariyerine büyük bir darbe indirmişti. İddialara göre birçok yanlış ve hatalı bilgi içerse de bu raporun, tarihin akışını değiştirecek kadar önemli bir belge olduğu ileri sürülmektedir ${ }^{29}$.

Murdoch bu görevi ifa ettikten sonra, mektubun bir kopyasını da, o dönemde Çanakkale Seferi'ne karşı olan Lloyd George ve diğer kabine üyelerine ulaştırmak için harekete geçti. İlk önce belgeyi The Times gazetesinin nüfuzlu editörü Geoffrey Dawson ve gazetenin sahibi Lord Northcliffe ile paylaştı. Lloyd George ve arkadaşlarının eline geçen mektup devlet sırrı olarak sınıflandırıldı. Ardından Çanakkale Seferi'ni geri çekilme ile sonlandıracak adımlar atıldı. Hamilton, Murdoch tarafından arzu edildiği şekilde görevden alınarak merkeze çekildi ${ }^{30}$. Murdoch yazdığı bu rapor ile Anzak efsanesinin temelini attığı gibi kaleme aldığı bu ikna edici hikâye ile ise başarılarla dolu kariyerinde bir adım daha ilerlerdi ${ }^{31}$.

\section{Murdoch'in Çanakkale Cephesi Raporu}

Gelibolu Mektubu olarak da bilinen Murdoch'ın raporu 8000 kelimeden oluşan gizli bir rapordur. Söz konusu rapor, dönemin Avustralya Başbakanı Andrew Fisher'a ve daha sonra Birleşik Krallık Başbakanı olan Henry Herbert Asquith’e gönderilmiştir. Birkaç sayfası Murdoch'ın yaptığı yazışmaları barındıran 28 sayfalık bu rapor, Gelibolu Seferi'nin bir felaket olduğunun farkına varılmasını sağlamıştır.

23 Eylül tarihli mektubun giriş kısmında Murdoch, gönderilme nedeniyle ilgili olarak askerlerin mektuplarının zamanında ulaştırılması noktasında postane departmanının hantal ve yetersiz olduğunu, böyle devam ederse hastanelerde yatan ve askeri üs depolarında çalışan bahtsız ve vatan hasreti çeken personelin büyük çoğunluğunun memleketlerinden mektup alma konusunda sıkıntı yaşamaya devam edeceklerini dile getirdi. Ancak asıl üzerinde durmak istediği şeyin daha mühim olduğunu, Avustralya Başbakanı'na yanındaymış gibi konuşacağını ve bu sefer Çanakkale Seferi hakkında yazacağını söyledi. Dediğine göre yazdıkları bizzat cephede alanda, telgraf aracılı-

28 Zwar, In Search Of Keith Murdoch, s. 22.

29 Jonethan Pearlman, "How Rupert Murdoch's father changed the course of the Gallipoli campaign", The Telegraph,(24.04.2015).

30 Serle, "Murdoch, Sir Keith Arthur (1885-1952)", s. 625, "Keith Murdoch: A new book examines Rupert Murdoch's father, Gallipoli, and the birth of the media dynasty", Independent, (20 October 2015), http://www.independent.co.uk/news/media/keith-murdoch-a-new-book-examines-rupertmurdochs-father-gallipoli-and-the-birth-of-the-media-a6701756.html (12.04.2017).

31 James Delingpole, "Without Gallipoli, we'd have no Page 3", The Spectator, 2 May 2015, https:// www.spectator.co.uk/2015/05/without-gallipoli-wed-have-no-page-3-says-james-delingpole/\# (12. 04.2017). 
ğıyla elde ettiği ve Misır'da öğrendiği bilgilere dayanıyordu. Ona göre tarihlerinin en talihsiz dönemlerinden birinde bulunmakla birlikte Başbakan Fisher'ın korkuları da haklı çıkmıştı. Kendisi bu askeri harekatın başarılı olup olamayacağına dair bir yargıya ulaşabilecek askeri bilgisi olmadığını kabul ediyordu. Ancak ona göre, kesin olan şey İngilizlerin karşı tarafı küçümsemeleriydi, yoksa şimdiye kadar birliklerin "yarlmadanın uçurumunda zayıf bir konumda yerleşmek yerine" daha az bedel ödeyerek İstanbul'a ulaşmaları gerekiyordu.

Murdoch satırlarına eleştirilerle devam ederek, Londra'nın yüzen ağır silahları dediği savaş gemilerine aşırı bel bağlandığının, ilk iki denemede birlikte hareket eden İtilaf donanmalarının Nisan-Mayıs aylarında "sefil" bir şekilde başarısızlığa uğradıklarının, üstelik dar Türk siperlerine karşılık, yatık mermi yoluna sahip silahlarla teçhiz edilmiş savaş gemilerinin çok az etki ettiğinin altını çizmektedir. Murdoch, sözlerine devam ederek Ağustos kara savaşlarını bir fiyasko olarak gördüğünü ve son deneme dediği 6-21 Ağustos tarihleri arasında gerçekleşen vuruşmalarda çok ağır ve kanlı bedeller ödendiğini söylemektedir. Başarısızlığın sorumlularını eleştirme noktasında sözünü esirgemeden bunun sebebini "acınası kurmay kararları" ile yetersiz sayıda ve niteliksiz askerlerin karaya çıkarılmasına bağlayan Murdoch'a göre bu başarısızlık neticesinde iki seçenek ortaya çıktı: Ya tüm birlikler geri çekilecek veya kışın geçmesi beklenip ondan sonra saldırılacaktı ${ }^{32}$.

Murdoch raporun bu kısmında bölgede çok kısa bir süre kalmış olsa da siperlerdeki komutanlarla, ast ve üst rütbeli kurmaylarla görüştüğünü, herkes tarafından sayg1 ve samimi bir itimat ile karşılandığını belirttikten sonra Hamilton'u eleştiren ifadelere yer vermektedir. Buna göre coğrafi olarak muhkem bir mevki olduğu için alınması çok zor olan ve fakat Hamilton'un bir baskın ile ele geçirmek istediği Ahi Baba'yı almak için inat etmesini kimse anlamamıştı. Murdoch'a göre burada alınan bir başka yanlış karar, Avustralya askerlerinin bu cepheye sürülmesiydi. Askerler Kabatepe'de kalsalardı çok az zayiat vermiş olan Avustralyalılar ilk savunma hattını da oluşturmuş olacaklardı. Murdoch'ın ifadesiyle, çok pahalıya patlayan Ahi Baba'yı kolaylıkla yerle bir etme planı en sonunda iptal edildi ${ }^{33}$.

Anzak birliklerinin yarımadanın içlerine doğru ilerlemeye teşebbüs etmediklerini, iç kısımlara ilerlemenin doğa şartları ve Ahi Baba menzilinde olunması nedeniyle mümkün olmadığını belirten Murdoch, Kanlı Sırt’ta askerlerinin yapabildiği ilerlemeden gurur duyulduğunu, ancak kendisinin böyle düşünmediğini ifade etmektedir. Yani ona göre alınan ilerleme kararı yanlıştır. Nitekim yine kendi ifadesiyle sırf 275 metre ilerleme için 2500 asker yitirmişlerdi. Ancak bu Anzakların yapabildiği tek ilerlemeydi. Bundan sonra Suvla Körfezi'ndeki durumdan bahseden Murdoch, buraya çıkarma yapan 90.000 askerin ciddi problemler yaşadığından, denizde 14 gün beklediklerinden, çıkarma gemilerinin yıpratıcı etkisinin yanı sıra, düşman denizaltısının gelme

32 Gallipoli Letter from Keith Arthur Murdoch, s. 1-2.

33 Gallipoli Letter from Keith Arthur Murdoch, s. 2-3. 
olasılığında dolayı askerlerin ciddi stres ve gerilimle karşı karşıya kaldıklarından bahsetmektedir. Murdoch'ın hemen çıkarma öncesinde askerlerin durumuyla ilgili şu canlı tasviri de dikkate şayandır:

"Düşünün ki o sirada amatör kurmaylar tarafindan idare edilen genç, tecrübesiz ve fazla eğitime tabi tutulmamış endişeli ve sıla hasreti çeken askerlerin moralleri, çıkarma zamanı yaklaştı̆̆ında yerindeydi. Çıkarma sırasında muhriplerde ve çıkarma gemilerinde askerler trol teknesinde tıkış tıkış balık istifi şeklinde durmak zorundaydl. Askerler bu pozisyonda öğleden sonraya hatta geceye kadar bekledi. Çıkarma gemilerine binmeden önce de yanlarına bisküvi ve sığır eti konservesinden oluşan üç günlük tayınları ve birer şişe sularını aldılar. Tüm bu hazırlıklardan sonra da askerlerin yaşamının en ucuz olduğu dönem olan çıkarma anı geldi ${ }^{\prime 34}$.

Murdoch raporun genelinde yaptığı gibi burada da Hamilton'u eleştirmekten geri durmamaktadır. Böyle tehlikeli bir görev için genç ve tecrübesiz askerlerin gönderilmesinin felakete davetiye çıkarmak olduğundan bahseden Avustralyalı, Hamilton ve kurmaylarının hatalı askeri kararlar vermemiş olsalar, askerlerin yetersizliğinden dolayı başarısız olunduğuna yönelik bahanelerinin bir dereceye kadar kabul edilebileceğini dile getirmektedir. Askeri çıkarma konusunda herkesin hem fikir olduğunu, Türk tarafının bu hareketi beklemediğini belirten Murdoch, bundan sonra Türk askerinin çıkarmaya karşı verdiği mücadeleden bahsetmektedir. Söylediğine göre çıkarmayı bilmeseler de, Türk askerleri çok hızlı hareket ederek topçu ateşine başlamış, mevzilerde bulunan toplar da yaylım ateşine katılmıştı. Bu doğrultuda Türk askeri yeni askeri birlikler gelene kadar, çıkarma yapılan alanın her tarafına bomba yağdırmıştı. Raporun devamında yine alınan yanlış kararlardan söz ederken, Anafartalar'ın işgali için yollanan askerlerin, hata anlaşıldığında geri çağrıldıklarını kaydeden Murdoch, buradaki başarısızlığın nedenlerinden biri olarak askerlerin muzdarip olduğu susuzluk meselesinin altını çizmekte ve bunun sorumluluğunu da yine kurmaylara şu şekilde yüklemektedir:

"Bir gün boyunca çıkarma gemisinde bekleyen ve sonra da karaya çıkan genç Ingiliz askerleri yanlarında getirdikleri suyu bitirmeye ve susuzluk çekmeye başlamıştı. Daha öğle vakti susuzluk askerleri yıpratmaya başlatmıştı. Kurmaylar böyle bir sıkıntının yaşanacağını hesaplayamamıştı. Bütün ordu tam ü̧̧ gün boyunca susuzluktan kırıldl. Birçok ölümün nedeni susuzluk oldu. Bir general bana Anafartalar'da yaşanan bozgunun nedeninin susuzluk olduğunu söyledi. Kesinlikle sıcakkanlı genç askerler, dünyanın en susuz kalan çocukları olarak tropikal sicakların yaşandiğ bu cepheye susamay tetikleyen yiyecekler ile yollanmıştı. Bir bölük komutanı, ordu kurmaylarının, kendilerini sınırları iyi hesaplanamamış emirler ile hem savaşılmaya gidilen bölgenin coğrafi özellik-

34 Gallipoli Letter from Keith Arthur Murdoch, s. 4. 
lerini bilmeden hem de susuz kalacak şekilde donatılmış olarak cepheye sürdügünden şikâyet etmekteydi" ${ }^{35}$.

Murdoch "bana ne anlatıldiysa elbette ben de onlart tekrar ediyorum ve yaptığım değerlendirmelere inanmanızı bekliyorum" dedikten sonra "ordu kurmaylarının Gelibolu'daki elim hatalarının gerçekten sefilce”" olduğunu kaydetmektedir. Yarımadanın alınmasına yönelik hazırlanan planın iyi olduğunu, tek eleştirinin Suvla Koyu'ndaki hareketlilik devam ederken, Anzak askerlerinin 971 no'lu tepe ile Conk Bayırı'na taarruza geçirilmeleri olduğunu belirten Murdoch, muhteşem Avusturya-Asya birlikleri dediği Gurkhas ve Connaught Muhafız Birlikleri'nin dağıldığgnı ifade etmektedir. Raporun bu kısmında 971 nolu tepe ile Conk Bayırı'na çok az Avustralya askerinin ulaştığını, bunların geri çekilmesinin şaşırtıcı olduğunu belirttikten sonra, İngiliz generallerinin arasındaki fikir ayrılıklarıdan söz etmektedir. Birbirleriyle problemli olan, merkeze çağrılan veya yeni görevlendirilen general ve komutanların isimlerini vermektedir. Müteakiben, 6-10 Ağustos tarihleri arasında, Suvla Koyu'nda gerçekleştirilen askeri operasyonların tamamıyla utanç verici olduğunu kaydeden Murdoch, sadece 1,5 mil kadar mesafe içeri girebildiklerini, ancak bir tane bile stratejik önemi haiz hâkim bir mevkii ele geçiremediklerini kaydetmektedir. "İtibarımızı biraz kurtaran tek başarı Mestantepe 'yi ele geçirmemiz oldu” diyen Avustralyalı, bu tepenin güvensiz ve Türk topçusunun menzilinde olduğu için sıklıkla bombalandığını ve bu bölgenin de tam manasıyla kontrol altına alınamadığını belirtmektedir.

Murdoch'1n söylediğine göre 6-10 Ağustos tarihleri arasındaki onun ifadesiyle "yaşadıkları berbat yenilgi neticesinde" Emperyalist Ordu'nun yaklaşı \% 35 'ini kaybetmişlerdi. Türk askerinin sayısı takriben 33.000 civarındaydı ve İtilaf kuvvetlerinden sayıca daha azd1. Fakat durum 21 Ağustos'ta değişti ve Türk ordusu takviye birliklerle güçlenip hücum pozisyonu aldı. Murdoch saldırı başladığında en vasıflı askerlerinin kanlı çarpışmalara girdiğini, şanlı dediği 29. Bölük'ün yaklaşık 40.000 askerini kaybettiğini ve mevcudunun 5.000'den daha aza düştüğünü belirtmekte ve buradaki yenilginin sebebinin de yine planlamayla ilgili olduğunun altını şu şekilde çizmektedir: "Burada benim eleştirim planlamaya yönelik oldu. Bu ĕgitimli ve vasıfl askerimizi biz neden Ağustos ayının başında kullanmadık ve neden şimdi biz bu askerleri bilerek ön hatta gönderip, Türklere öldürttük!’’36.

Murdoch raporunun bu kısmında Anzak efsanesinin temellerini atacak ifadelere yer vermekte Avustralya ve Yeni Zelanda askerlerinin başarılarından bahsetmektedir. Ona göre Anzak Koyu'nda yer alan ve "kahramanca" ilerleyen Avustralyalı Gurkhas ve Connaught Muhafiz Birlikleri ve Yeni Zelanda ileri karakolunda yer alan askerler, "bitmek tükenmek bilmeyen enerjileri" ile sol cenah ile merkezin birbiri ile bağlantılı olmasını sağlamışlardı. Yeni Zelanda yivli tüfekleri, tepelerde yer alan keskin nişanc1ların neredeyse tamamını yok etmişti. Bu sayede Wellington Taburu, diğer Yeni Zelandalı birlikler ve “Şanll” Dördüncü Tabur'un 4000'den fazla askeri cephede ilerleye-

35 Gallipoli Letter from Keith Arthur Murdoch, s. 5-6.

36 Gallipoli Letter from Keith Arthur Murdoch, s. 6-8. 
bilmişti. Geceleri kesik, fundalık ve oldukça zorlu arazide "kahramanca" ilerleyen bu askerlerin çabası, yanlış yönlendirme ve devamlı yaşanan süngü süngüye çarpışmalar nedeniyle kesilse de, Çanakkale Seferi içindeki “en şanll” mücadelelerinden biriydi. Kahramanca ve şanlı gibi kelimelerle yücelttiği askerlerin küçük bir tepe olduğunu söylediği Conkbayırı'na çok azının ulaştığını ve orada bulunan 5000 Türk askerine karşı umutsuzca yumruk yumruğa savaştıklarını belirten Murdoch, operasyonun başarılı olması için gerekli olan asker miktarına sahip olmadıklarını şu çarpıcı ifadelerle dile getirmekte, son cümlesinde ise yine Avustralya askerlerini övmektedir:

"Biz bu operasyonun başarılı olması için yeterince askere sahip değildik. Yeterli gücümüz yoktu. Maalesef hedefimizi yüksek koymuştuk. Orada kafi derecede askerimiz olmayınca doğal olarak tutunamadık. Hatta Anafarta Tepeleri bizim desteklerimiz ile tutulmaya çalışılsaydl, biz yine de son derece önemli olan Conkbayırı'nı mevcut askerler ile elde tutmayı başaramazdık. Kahraman Dördüncü Tabur'un asker sayısı 1000 civarına indi. Bilmekten mutlu olacağınızı düşünüyorum; askerlerimiz kahramanca öldüler" ${ }^{37}$.

Murdoch Avustralyalı askerleri övdüğü satırlarını müteakip karşılaştıkları sorunları dürüst bir şekilde ele alacağını, önlerinin kış ve kışın çok ciddi sorunlarla karşılaşabileceklerini belirtmekte, asker sayısı ve bulundukları yerler hakkında bilgi vermektedir $^{38}$. Bu ifadelerinin ardından Türk topçusuyla ilgili detaylar veren Murdoch topçulardan hiçbir yerde korunamadıklarını belirtmekte ve bunun sebeplerinin üzerinde durmaktadır. "Elde tutabildiğimiz mevzi sayısı çok azdı ve Türklerden saklanamıyorduk" şeklinde burada raporuna kayıt düşen Murdoch, silahlarını konumlandırmada sorun yaşadıklarını ve kazandıkları mevzileri her seferinde kaybettiklerini açık yüreklilikle ifade etmektedir. Murdoch'ın raporun bu kısmında Türk topçusunun başarılı olmasıyla ilgili düşünceleri de dikkate değerdir:

"Türkler daha geniş bir arazide toplarını uygun pozisyonlara konumlandırarak ve kolaylıkla yerlerini değiştirerek onları yok etmemizi engelliyorlardl. Anzak Körfezi'nin sağında yer alan toplara zarar vermenin imkânsız olduğunu görseydiniz şaşırırdınız. Bu toplar Kilitbahir platosu içinde yer alan zeytin koruluklarına gizlenmişti. Savaş gemileri ve oldukça etkili ve modern toplarımız, bu silahlara zarar veremiyordu. Bu toplardan doğrudan üzerimize, sahilde yer alan birliklerimize ateş açıllyordu ve bu çok ciddi zararlara yol açıyordu. Konumlandığımız üç yer o kadar saldırıya açıktı ki, Türklerin bizi topçu atışları ile neden sahilden söküp atmadı̆̆ıı anlayamıyorduk. Sadece Seddülbahir bölgesi

37 Gallipoli Letter from Keith Arthur Murdoch, s. 8-9.

38 Murdoch'ın burada verdiği bilgiler şu şekildedir: "Yarımadada 105.000 civarı askerimiz, 25.000 civarı hayvanımız, bunların yüzde doksanı katırımız var. Askerlerimizin yaklaşık 25.000 tanesi Seddülbahir Koyu'nda, 35.000 tanesi Anzak Koyu'nda ve geri kalanı ise Suvla Koyu'nda yer almaktadır. Avustralyal birliklerin sol cenahtaki kahramanca çabalarl sayesinde, Suvla ve Anzak'da yer alan birlikler birleşebildi. Ama unutmamak gerekir ki, Suvla Koyu'ndan biri Anzak körfezine diğeri de denize olmak üzere iki kez geri çekildik. Bunlar toplam 260.000 civarl askerden geriye kalanlardl" Gallipoli Letter from Keith Arthur Murdoch, s. 9. 
biraz daha güvenliydi. Anzak ve Suvla körfezlerinde yer alan birlikler tamamıyla açık hedef halindeydi. Ĕger Türkler yeterince modern toplara ve mühimmata sahip olsalardl, Suvla ve hatta ondan kötüsü Anzak bizim için yaşanabilecek bir alan olmaktan çıkabilirdi" 39 .

Murdoch'ın raporun bu kısmında söylediğine göre, İngiliz kurmaylarının Türk askerinin ne kadar mühimmata sahip olduğu konusunda farklı tahminleri vardı. Ona göre tek emin olunan şey, Türk tarafının mühimmat durumunun İtilaf tarafından daha kötü olduğuna inanılmasıydı. Halbuki Murdoch, Türklerin mühimmatlarını kışın yapacakları saldırı için sakladıkları savına da inanmıyordu. Bunun sebebi Türk topçusunun sahilde demirlemiş olan çıkarma gemilerine gereksiz yere ve gelişi güzel ateş etmesiydi. Söylediğine göre Türk topçusu çıkarma gemilerini sıklıkla vurabiliyordu ancak bu atışlarını ciddi bir şekilde yapmıyorlardı. Bir ara iki tane çıkarma gemisine sekiz kez ateş ettiklerini görmüştü. Yine bir gün Yeni Zelanda sahilinin sağ cenahından üzerlerine 60 defa top atışı yapılmıştı. Bu saldırı nedeniyle 65 asker kaybetmişlerdi. Murdoch'a göre Türk askerinin verdiği bu zarar, yeterince mühimmata sahip olduklarının da bir göstergesiydi ${ }^{40}$.

Murdoch burada yine olumsuzluklardan bahsederken, maliyeti göz önüne almadan dalgakıran inşası için çalışan iki buharlı geminin battığını, Anzak Koyu’nda bir tane açık demirleme alanı olduğunu ve kendilerinin üç adet küçük iskele inşa edip bu iskelelerin bir tarafını, askerlerini top atışından korumak için kum torbaları ile desteklediklerini kaydetmektedir. Suvla Koyu'nda daha fazla gemi battığını belirten Murdoch çıkarma yapmak için güvenli tek bir alan olmadığg şeklinde bir değerlendirme yaparak, doğal şartların da başarısızlıkta payı olduğunu ima etmektedir ${ }^{41}$.

Genel itibariyle bu türlü olumsuzlukların tasvir edildiği raporun bu kısmında Murdoch iki önemli husus üzerinde durmaktadır. Bunlardan ilki savaş alanında ele geçirilen bölgelerindeki mevzi, mühendislik vb. çalışmaların kışın burada kalınmayacak şekilde hazırlanmasıydı. İkincisi ise daha önemli bir mesele, su problemiydi. Avustralyalının bu iki konudaki değerlendirmeleri şu şekildeydi:

"Kışı geçirmek için ciddi büyüklükte yapısal değişikliklere ve iyi yollara ihtiyaç vardl. Korkarım ki bu konuda karar vermek için çok geçti ve yapılacak değişikliklerin kışa yetişmesi mümkün gözükmüyordu. Anzak Körfezi'ni terk ettiğimde inşaat malzemeleri daha gelmemişti. Ayrıca sadece 14 günlük erzakımız kalmıştı. İklimden önce, su sıkıntısını çözmek gerekmekteydi. Elverişsiz hava koşulları, denizden karaya su taşınmasını engelleyebilirdi. Bu durumda birliklerimizin yaşadiğı büyük sıkıntılara su sorunu da eklenecekti. Bir ay boyunca su rezervinin olmaması kafalarda son derece tehlikeli bir sorunun varliğ anlamina gelecekti" ${ }^{42}$.

39 Gallipoli Letter from Keith Arthur Murdoch, s. 9-10.

40 Gallipoli Letter from Keith Arthur Murdoch, s. 10.

41 Gallipoli Letter from Keith Arthur Murdoch, s. 11.

42 Gallipoli Letter from Keith Arthur Murdoch, s. 11-12. 
Murdoch askeri bakımdan Anzak Koyu'nda durumlarının iyi olduğunu düşünüyor ve "bizi buradan söküp atamazlar" diyordu. Yine kendi milletini överek Avustralyalı "pratik zeka ve dayanıklılığının” bu koyu kaleye çevirdiğini, gözü pek ve kararlı askerlerinin bölgeyi koruduğunu belirtirken, Suvla Koyu'nda ise ciddi tehlikelerin varlığından bahsetmektedir. Murdoch'ın korkusunu özellikle en çok kamçılayan şeyin Almanlar olduğu buradaki ifadelerinden anlaşılmaktadır. Söylediğine göre kış döneminde Suvla'yı elde tutmak mümkün olmayabilirdi dahası büyük ihtimalle Alman ordusu da cepheye gelecekti. Onun ifadesiyle her durumda, ağır silahlar ile donatılmış Alman ordusunun cepheye gelmesi onlar için sonun başlangıcı, bu seferin sonu olabilirdi. Büyük Alman obüsleri siperlerini paramparça edebilirdi ve onların bu saldırılara karşılık vermesi de mümkün değildi. Bomba Sırtı (Quinn's Post) gibi bazı bölgelerde çok az bir alanın kontrol edilebildiğini belirten Murdoch'ın öngörüsü, Alman silahları cepheye gelsin gelmesin Türk tarafının kışın ciddi bir şekilde saldıracağı yönündeydi: "Onları hiçbir şekilde tehdit edemeyeceğimizi anladıklarında, toplarını bir araya getirip üzerimize saldırabilirlerdi. Ayrlca kalede yer alan büyük topların istedikleri alana taşlyabilir ve bizi ciddi şekilde hirpalayabilirlerdi",43.

Murdoch raporun bu kısmında askerin karşı karşıya kaldığ 1 bir başka ciddi problem, yani hastalıklar üzerinde durmakta ve bu konu hakkında bilgiler vermektedir. Hastalıkların askeri güçlerini korkunç derecede zayıflattığını belirten Murdoch'a göre, sivrisinekler çoktan dizanteri hastalığının alarm seviyesinde yayılmasına sebep olmuşlard1. Askerler arasındaki hasta oranı şaşılacak derecede yüksekti ve her gün en az 600 asker hastalıktan dolayı muayene, 1000 civarında asker ise yarımadadan tahliye ediliyordu. Murdoch bu konudaki görüşlerine Avustralyalı askerleri övdüğü şu sözlerle devam etmektedir:

"Sonbahar yağmurları başladığında, siperlerin dibinde gelişi güzel gömülen askerlerimizin üzerindeki toprak örtüsü ince olduğu için aşınacak ve bu nedenle bulaşıcı hastalıklar zuhur edecek. Şimdi bile siperlerde ortaya çıkmış olan kötü koku askerleri hasta etmektedir. Yazık, iyi askerlerimiz burada gömülü, cesur yürekleri atmıyor, acı Avustralyalı ailelerimizi çok sert bir şekilde vurdu" $" 44$.

Yazdığ1 raporda gazetecilik hünerlerini sergilemekten çekinmeyen Murdoch bu ifadelerini müteakip yine bu konudaki öngörülerine devam etmektedir. Kışın hastalıklar nedeniyle 30.000 civarında asker kaybedildiği takdirde ilkbahar geldiğinde ellerinde sadece 60.000 civarında asker kalacağını öngörmektedir. Ona göre bu askerlerden kesinlikle bir ordu olmayacak, bozguna uğramış ve harcanmış askerler olacaktı. Topçu ateşi ve ani baskın tehdidiyle, güç şartlar altında Gelibolu'da geçirilecek bir kış, askerlerinin yıpranmış mevzilerinde daha elim ıstıraplara gark olmalarına neden olacaktı. Soğuk ve yıpratıcı kış gecelerinde eller tetikte bekleyen ve bu nedenle yıpranmış olan askerlerden, savaşma vakti geldiğinde çok fazla bir şey beklememek

43 Gallipoli Letter from Keith Arthur Murdoch, s. 12-13.

44 Gallipoli Letter from Keith Arthur Murdoch, s. 13. 
gerekirdi. Eğer yeni bir saldırıya girişeceklerse, bu saldırı, kış boyunca yıpranmış askerler ile değil, yeni askeri birlikler tarafından yapılmalıydı. Yeni askeri birlikler yardımlarına gelecek mi idi? O sırada Fransa' dan gelen şikâyetlere baktıklarında, personel eksikliğini gidermeleri imkânsız gözüküyordu. Zayıflamış askeri kademelerin yenilenmesi mümkün görünmüyordu. Murdoch raporun bu kısmında savaşı devam ettirme noktasındaki düşüncelerinde kötümser bir tavır sergilerken, Avustralya askerlerini yine yüceltmektedir. Kötümser değilim dedikten sonra, bu berbat çile için askeri bir operasyon şart ise, eminim ki bizim Avustralyalı askerlerimiz ellerinden geleni yapacaklar şeklindeki ifadeleriyle onlara yönelik methiyelerini devam ettirmektedir ${ }^{45}$.

Murdoch raporun bu kısmında Çanakkale cephesinde askerleri tutmanın ne tür genel siyasi sonuçlar doğuracağı üzerine çeşitli değerlendirmeler yapmakta ve bu konuda kabindeki bakanların fikirlerini paylaşmaktadır. Bakanların Çanakkale' de yaşanacak bir başarısızlığın İran ve Hindistan'da da önemli sorunlara yol açacağı fikrine katılan Murdoch, İran'da ciddi problemlerle boğuşulduğunu, Hindistan'ın ise sorun çıkmaya çok müsait olduğunu kaydetmektedir. Korkunç harcamalar yapılarak devam ettirilen bu savaşın başarılı olacağını düşünmeyen Murdoch, sırf Almanya'nın ekonomik gücünü yıpratmak için girdiklerini düşündüğü savaşın, gelir kaynaklarını tüketeceği kanaatini taşıyordu. Bir sonraki yıl İstanbul'u ele geçirmek için yapılacak bir seferin başarı şansı konusunda da şüpheli olduğunu belirten Avustralyalı boğazları geçebilmek için yeterli askeri destekten başka çıkar yol olmadığını düşünüyordu. Bu sefer için gerekli olan asker sayısını verdikten sonra ise Türk siperlerinin ne kadar muhkem mevkiler olduğuna dair detaylarla satırlarına devam etmektedir. Ona göre fevkalade bir şekilde tahkim edilmiş derin ve dar mükemmel Türk siperlerinin üzerleri ağır kalaslar ile kapatılmış ve her türlü top atışına ve saldırıya karşı hazırlanmış durumdaydı. Üstelik Avustralyalıların mevcut halleri de ortadayken Türklere saldırmak yarar getirmeyecekti. Murdoch, savaşta hayatlarını kaybeden Avustralya askerleriyle ilgili en dramatik ve trajik tasviri burada şu şekilde yapmaktadır: “Ölü Adam Sırtı'nda (Dead Men Ridge) cesurca birkaç yüz metre ilerlemeye çalışan en vasıfl Hafif Süvari birliklerimizin on dakika içinde yok edildiği alana ben ve savaş şairi Hughes (Ted Hughes) ile gelseydiniz kesinlikle gözyaşlarına boğulacaktınız. O dehşet bölgede kimi gecekonduda oturan, kimi çiftçinin oğlu 500 askerimizi kaybettik"46.

Murdoch bundan sonra askeri birlikler hakkında daha doğru bir ifadeyle askerlerin durumlarıyla ilgili detaylı bilgiler vermektedir. Askerlerin morallerinin bozuk olduğundan, özellikle Suvla Koyu'ndaki askerlerin yeni gelmiş olmalarına rağmen durumlarının çok kötü olduğundan bahsettikten sonra belki de İtilaf kuvvetleri için hezimetin en önemli sebebi olan askerlerin komutanlarına güvenmediklerinin altını çizmektedir. Söylediğine göre askerler sadece oradaki komutanlarına değil, Londra’ya da artık güvenmiyorlardı. Bir İngiliz yüzbaşısına kış hazırlıkları için artık karar vermesi gerektiğini söylediğinde, suratını ekşitmesini asla unutamayacağım diyen

45 Gallipoli Letter from Keith Arthur Murdoch, s. 13-14. 
Murdoch'ın bir diğger tespiti, askerlerin üzerinde halen tropikal-yazlık bölgelere göre hazırlanmış kıyafetler olmasıydı. Kendisi Çanakkale'yi terk ettiğinde bile Londra'dan gönderilen yeni askerlerin yazlık kıyafetlerle yollandığını, Çanakkale'deki askerlerin kendi kaderleri ile baş başa bırakılacakları korkusu taşıdıklarını kaydeden Avustralyalı, askerlerin durumu ve güvensizliklerinin temel sebebinin başta Hamilton olmak üzere kurmayların yanlış kararlarından kaynaklandığını şu sözlerle vurgulamaktadır:

"Hamilton ve kurmay subaylar, verdikleri kararlar ile birlikleri çımaz sokaklarda harcadılar. Suvla Koyu'nda olanları kendi gözlerinizle görseniz zor inanırdınız. Yapılan hataları gördügünüzde bu askerlerin İngiliz askeri olduğuna inanmazdınız. Askerler uğradıkları zavallıca yenilgilerden, ortamdan, su sikıntısı yaşamaktan, tuzlu dana eti ve diyet pirinç yemekten zihinsel körlük çekmekteydiler ve vücutları şoka girmişti...Askerler sanki eziyet görmüş aptal hayvanlar gibi baklyorlardi" "47.

Mudoch'ın raporundaki en garip yaklaşımını bu kısımda sergilediğini görüyoruz. Suvla Koyu'ndaki askerlerden bahsederken, buradaki Britanyalı askerlerin fiziksel durumlarının, Türk askerlerininkinden daha kötü olduğunu belirttikten sonra bir gazeteciden beklenmeyecek türde savaşma konusunda tereddüt edenlerin vurulmasına yönelik sözler sarf etmektedir: "Bu cümleyi dikte etmekten hoşlanmıyorum ama Suvla Koyu'ndaki ilk günden itibaren, kararl ve acımasız bir şekilde ilerlerken geride kalan veya bilerek geride oyalanan askerlerin vurulmast emri verilmeliydi". Murdoch'ın burada kast ettiği askerlerin İngiliz olduğu, bir sonraki kısımda onlarla ilgili daha ağır ifadelerinden anlaşılmaktadır. Bunun tersine müteakiben Anzak askerlerini ise yine yüceltmektedir. Üstelik Anzak Koyu'ndaki askerlerin morallerinin yerinde, fakat yeni gelenler hariç, çoğunun cesaretinin kırılmış olduğunu belirtmekte, Yeni Zelandalı ve Avustralyalı askerlerden oluşan Godleys Birliği’nin büyük zayiata uğrasa da asla geri çekilmediğini dile getirmektedir. Kendi askerlerini kastederek bu ırkın içindeki savaşçı ruh bu askerlerde canlıdır dedikten sonra İngilizleri kastederek, bunu Suvla Koyu'ndaki oyuncak askerler için söylemek mümkün değildir demektedir. Murdoch'ın neden Anzak Efsanesi'ni yaratan kişi olduğunu anlamak için raporun bu kısmında kendi askerleriyle ilgili söyledikleri şu sözlere bakmak yeterlidir:

“...Tahmin edebileceğiniz üzere, ben Ege’de gemideyken gördüğüm iyi aileler tarafindan yetiştirilmiş, çıkarma gemisinde balık istifi savaşmak için bekleyen Avustralyalı askerler, evlerine dönmek için utanmadan İskenderiye'deki birliklerinden kaçan askerlerden çok daha değerlidir. Anzakların kutsal topraklarında savaşan bu askerler her şekilde, bahsi geçen kaçak askerlerden değerlidir. Bu değerli vatan evlatları, muhteşem askerler, askerden kaçmanın onur kırıcı olduğunun farkındaydı. Ölüm onlar için bir sorun değildi. Bu askerlerin hayata bakış açıları ne kadar muhteşem! Bu delikanlılar nasıl öleceklerini tartışıyorlardı. Onlar için Anzak'ta toz altında yatan hayatını kaybetmiş kardeşinin yanında ölmek kadar şerefli bir şey yoktu... Avustralyalı birliklerin

47 Gallipoli Letter from Keith Arthur Murdoch, s. 15-16. 
ihtişamina dair size daha çok şey söyleyebilirim. Askerlerin birbirlerine ve vatanlarına karșı bağlllıkları ve ne muhteșem bir sevgi beslediklerini anlatabilirim. Bu sayede Avustralyalı olmanın verdiği duygu sizde en üst seviyeye çıkabilir. Bu askerleri görmek çok heyecan verici, Anzak'ta yürürken kollarını sallayan muhteşem insanlar! Onlarda insanlığın bu zamana kadar taşıdığı asil yüz var. Anzak'ı benim gördüğ̈̈m gibi tahayyül ederseniz, Avustralyalı olmanın dünyanın en önemli imtiyazı olduğunu göreceksiniz..." 48 .

Anzak Koyu'ndaki askerlerin morallerinin yüksek olmasının nedenini onların fiziksel özelliklerine bağlayan Murdoch, Avustralya askerlerinin başındaki komutan William Birdwood'a çok güvendiklerini belirttikten sonra Ian Hamilton için ise endişeli olduğunu ifade etmektedir. Murdoch, Hamilton'un kurmaylarının kibirli olduklarını ve bunu göstermekten çekinmediklerini belirtirken, askerlerin arasında isyan fikrinin olduğundan da söz etmektedir. Söylediğine göre askerleri isyan etmekten alıkoyan şey bağlılıklarıydı. Aslında geri dönen her çıkarma gemisinde ve iletişim hattında isyan ile ilgili konuşmalar vardı. Kendisinin Hamilton'u sevdiğini, onun gerçekten kibar birisi olduğunu, bir gazeteci olarak ona hayranlık duymasına rağmen, bir strateji uzmanı olarak kesinlikle başarısız olduğunu düşünüyordu. Murdoch bu olumlu ifadelerinin ardından asıl niyetini çok net ifadelerle ortaya koymaktadır. Ve bunu yaparken de Hamilton'un İtilaf askeri nazarındaki durumunu şu ilginç benzetmeyle desteklemektedir: "Şüphesiz ki morali bozuk ve bozguna uğramış olan askerlerin moralini düzeltmenin en önemli ve ilk adımı Enver Paşa'dan bile daha fazla nefret edilen Hamilton'ı ve kurmaylarını görevden almaktır'. Müteakip cümlelerde Hamilton'u eleştirmeye devam eden Murdoch onun görevden alınmasından başka bir çare kalmadığını, yüksek ihtimal mektup başbakana ulaşmadan Hamilton'un görevden alınacağını ifade etmektedir. Ona göre Suvla Koyu'nda yaşanan felaketten sonra, bu yarımadaya yeniden yüz binlerce asker getirmeleri şarttı ancak bu şekilde başarı11 olabileceklerini düşünüyordu. Bütün bu takviyelere rağmen, yerlerinde sayarlarsa bundan daha utanç verici bir şey olmayacağını kaydeden Murdoch, Hamilton gibi bir komutanı "yargllamak bana düşmez" dese de, yalın gerçekler olduğunu söyledikten sonra istifa etmesi gerektiğini ima eden ifadelere yer vermektedir. Ona göre bir ordu, komutanına karşı güvenini tamamıyla kaybettiği zaman -Hamilton birçok kez zayıf bir komutan olduğunu ortaya koydu- yapılacak tek şey vardı. Murdoch sözüne eleştirilerle devam etmekte Hamilton'un Gökçeada'da ikamet edip Anzak Koyu'na hiç gelmediğini, Fransızların onu adada yaşayan general olarak tanımladıklarını belirtmektedir. Bu iddialar doğru olmayabilir dedikten sonra Hamilton'un, Suvla için “ $\mathrm{Her}$ şey kontrol altında! Gönüllü Süvari Alayı saldırıya geçecek” açıklamasının onu alay konusu haline getirdiğini, askerlerin Hamilton'u sözde her şey kontrol altında iken cepheyi terk eden komutan olarak görmeye başladıklarını ifade etmektedir ${ }^{49}$.

48 Gallipoli Letter from Keith Arthur Murdoch, s. 16-18. 
İstese mektubu daha fazla uzatabileceğini ve o ana kadar yazdıklarının olanların ve durumun sadece çok az bir kısmı olduğunu kaydeden Murdoch raporun bu kısmında İngiliz generallerine yönelik eleştirilerinin dozunu biraz daha arttırmaktadır. Ona göre, bu korkunç ve beceriksizce yönetilen Çanakkale Seferi'ni sürdürmek ve "kırmızı tüy takmış kibirli ve kendini beğenmiş kapasitesiz Britanyalı generaller" tarafından yönetilen ordudan başarı beklemek büyük hataydı. Özellikle Mondros'tan gelen yazılardan edindiği intibaya göre birçok üst rütbeli kurmay ve kendini beğenmiş "terbiyesiz" genç, savaşı bir oyun olarak algılamaktaydılar. Ona göre, ciddi olarak hayatında hiç çalışmamış sadece giyimine, sosyal statüsüne ve kendini tatmin etmeye odaklanmış bu insanlardan ne beklene bilirdi ki? Murdoch böyle ağır ifadelerle tenkit ettiği Britanyalı kurmaylar ile muhatap olan Avustralyalıların tamamının bu adamlardan tiksindiklerini ve onlardan nefret ettiklerini kaydetmektedir. Eleştirilerine somut örnekler vererek devam eden Avustralyalı, birçok skandaldan bahsedebileceğini belirtip iki hadise hakkında bilgi vermektedir. Birincisi Mondros limanına demirlemiş Aragon adındaki gemi mürettebatının (iletişimden sorumlu kurmaylar) lüks içinde yaşarken, tifo gibi hastalıklardan muzdarip 134 Avustralya askerine gerekli olan buzu temin etmemeleri (Murdoch'a göre buz içinde yüzüyorlardı), diğeri ise 150 civarında yaralı askerin hiçbir önlem ve talimat olmadan hastanenin kumsalına indirilmesi ki Murdoch bunun sorumlusunun da Aragon çalışanları olduğunu kaydetmektedir ${ }^{50}$. Bu ifadelerini müteakip yine eleştirilerine devam eden Murdoch, Mısır'daki kötü durum ve bunun sorumlusu olarak gördüğü İngiliz komutan Sir John Maxwell'den bahsetmektedir. Sahip olduğu pozisyona nazaran küçük bir beyne sahip diye küçümsediği hatta aşağıladığı Maxwell'in derslere konu olacak meşhur hatalar yaptığından, M1sır'da meydana gelen ve Avustralyalı askerlerin de karıştığı olayların baş sorumlusu olduğundan söz etmektedir. Bu olay esnasında özellikle yakılan evlerin bilerek ve istenerek yapılan bir cinayet olduğunu ve Avustralyalıların da böylece Kahire'de suç işlediklerini kabul etse de, asıl sorumlunun İngiliz general olduğunu belirterek, kendi

50 Murdoch'ın bu iki konudaki ifadeleri şu şekildedir: “Aragon isimli, İletişim Generali- Müfettişi kurmaylarına ev sahipliği yapan lüks Güney Amerika yolcu gemisi, Mondros limanına demirledi. Bu gemide çalışan yeni subaylardan hem Britanyalı hem de Avustralyalı subayların nasıl iğrendiklerini gördüm. Bu gemide çalışanlar lüks içinde yaşıyordu. Bu adamların cepheden gelen askerlere yaptı̆̆g kabalığl kimse geçemez. Gemi emir subayının yaptı̆̆ büyük kabalıklara, burnu büyüklüklere ve acziyete hayatım boyunca hiç rast gelmemiştim. Aleni yeteneksizlik bu çalışanların karakterlerinin temel özelliğidir.. Bu olaya ilaveten daha somut örnek vermem gerekirse, bir gün gecenin karanlığında 150 civarı yaralı asker, hiçbir önlem ve talimat olmadan hastanenin kumsalına indirildiler. En klsa zamanda hastaneye yetiştirilmeleri gerekiyordu ama bu askerlerin karaya getirildiği bilgisi kimseye verilmemişti. Bütün bu rezaletin sorumlusu, iş yapmaktan aciz Aragon çalışanlarıydl. Bu konuda bilgiyi Fiaschi, de Crespigny, Stawell ve Kent Hughes'den alabilirsiniz. Ben oradayken, bir general ve ekibi, gelen yaralıları teftiş etmek için oraya gitti. Generalin gelmesiyle, yaralılar ve hastalar için Aragon'dan buz alabileceğimizi ummuştum. Fakat bir gün geçmesine rağmen oradan buz yollanmadl. Fakat donanma buz ve yardım malzemeleri göndererek elinden geleni yaptı. Ancak ben hastaneye gelmeden önce, gönderilen buz hastaneye ulaşmadan heba edilmişti..." Gallipoli Letter from Keith Arthur Murdoch, s. 20-22. 
askerlerini "bilerek suç işlediklerine dair hiçbir bilgi ve suçlama duymadım” diyerek temize çıkarmaktadır ${ }^{51}$.

İngilizleri ve daha ziyade Hamilton’un kurmay sınıfını adeta eleştiri bombardımanına tutan Murdoch'ın raporunda Türk askeri hakkındaki en net ifadelerini raporun bu kısımda verdiğini, ama bunu yaparken bile yine kendi askerlerini yücelttiğini görüyoruz: "Gördüğüm kadarlyla Türkler cesur ve yüce gönüllü düşmanlar. Onlar kendi vatanları için çarpışıor, bu savaşı kazanmakta olduklarını hissediyor ve kendilerinin çarpıştıkları askerlerden daha iyi olduğuna inanıyorlar'. Murdoch'ın buradaki ifadelerinde ilginç olan geleceği görüyormuşçasına söylediği Türk tarafının savaşı kazanmakta olduğu şeklindeki sözleridir. Bunu müteakip kendi askerlerini yüceltirken Türk askerinin Avustralyalıları takdir edip onlardan çekindiklerini şöyle dile getirmektedir. "Türkler, Avustralyall askerlerin verdiği mücadeleyi ise hem Ingilizler hem de Fransızlardan daha fazla takdir etmektedir. Kesinlikle, pozitif bir şekilde ifade etmeliyim ki, Türkler, Avustralyalı askerlerden çekinmektedir. Bomba Sırtı'nın karşısında yer alan siperlerinde, Türkler bizim keskin nişancılarımızdan ve bomba atan askerlerimizden korkmaktadır. Zira onlara önemli ölçüde kayıp verdirdik". Murdoch bu ifadelerinden sonra Türk askeri hakkında son derece müspet sözler sarf etmekte, insaniyet ve cesaret kelimelerini Türk kelimesi ile birlikte şu şekilde kullanmaktadır: "Türkler ile ilgili ifade etmem gereken önemli şeylerin başında onların gösterdiği insanlık ve cesaret gelir. Insanliğın ve cesaretin birçok örneğini fevkalade düzeyde gösteren Türklerin en önemli şansı, daha güçlü ve sağlam siperlere sahip olmalarıdır. Bu sayede bizden daha fevkalade ve hızlı bir şekilde savaşabildiler" "52.

Murdoch Türk askeri hakkındaki bu müspet ifadelerinden sonra sağlık işlerinden sorumlu olan bir İngiliz yetkiliyi ciddi bir şekilde eleştirmekte, Savunma Bakanlığı'nın bu “beceriksiz” adamı görevde tutarak, muhtemel kış aylarında ortaya çıkabilecek sorunları çözmesini beklemesini anlayamadığını ifade etmektedir. Devamında durumu umarım olduğundan daha kötü bir şekilde sunmamışımdır diyerek, Türk tarafının da problemleri olduğunu, ancak seferin yersiz ve başarısız olduğunun altını çizmektedir. Raporunun son kısmında ise başarı için, deneyimli ve güçlü askeri birlikler ile bu birlikleri yönetecek büyük bir lidere ihtiyaçlarının olduğunu belirterek, Hamilton'un görevden alınması gerektiğini kastetmiştir. Kurmay subayların, kendilerini kahramanca kurban eden askerleri gibi, bu mücadele için kendilerinden ödün vermesi gerektiğini belirttikten sonra, şu an yukarıda bahsettiklerimden hiçbirine sahip değiliz, diyerek sözlerine şu şekilde son vermiştir: "Askeri birliklerimiz ikinci sınıf askerlerden oluşmaktadır ve daha kötüsü bu askerler yarımadada yokluk içinde savaşmak zorundalar. Bundan kötüsü kurmay subayların vasifsız ve bencil olmasi. Murdoch Avustralya başbakanına yazdığı mektubuna, "Size daha fazla bilgi aktarmak isterdim, lakin buradaki görevim bitti. Size yine yazacă̆ım. Umarım bu yazacă̆ım mektup güzel haberler ile dolu olur" diyerek son vermiştir ${ }^{53}$.

51 Gallipoli Letter from Keith Arthur Murdoch, s. 22-23.

52 Gallipoli Letter from Keith Arthur Murdoch, s. 23.

53 Gallipoli Letter from Keith Arthur Murdoch, s. 23-25. 


\section{Sonuç}

Dünya'nın tecrübe ettiği ilk büyük savaşın seyrini değiştiren Çanakkale Cephesi'ndeki gelişmeler, gerek Osmanlı kamuoyu gerekse Avrupa ve dünya kamuoyunca yakinen takip edilmiştir. Bu noktada kamuoyunun haber kaynakları genelde gazeteciler özelde ise savaş muhabirleri olmuştu. Bu minvalde yerli ve yabancı birçok gazeteci Çanakkale Cephesi'ni ziyaret etmiş, gelişmeleri kendi kamuoylarına aktarmıştı. E. A. Bartlett gibi ünlü birçok savaş muhabirinin yazdıklarının Çanakkale Cephesi'ndeki yaşanmışlıkları bugün anlamamıza yaptığı katkının son derece önemli olduğunu söylememiz gerekir. İtilaf Devletleri nokta-i nazarından bakıldığında, cepheye gelen gazetecilerden birinin yazdıklarının cephenin kaderinde derin bir iz bıraktığını görüyoruz. Bu kişi ileride adeta büyük bir medya imparatoru olacak olan Keith Arthur Murdoch'tır.

Avustralya hükümeti tarafindan Çanakkale'ye gönderilen Murdoch'ın cephedeki gelişmelerle ilgili tespitlerini içeren raporunda üç hususun ön plana çıktığını söyleyebiliriz. Bunlardan ilki başta General Ian Hamilton olmak üzere İngiliz kurmay heyetinin yaptığı hatalar ve bu hatalar neticesinde ortaya çıkan başarısızlığa yapılan vurgu. İkincisi, Anzakların bu gün bir efsane haline gelmiş olan savaşta gösterdikleri tutumun tasviri. Yani Anzak efsanesinin oluşmasına yaptığı katkı. Üçüncüsü ise diğer iki unsura nazaran metinde kapladığı alan az olmakla birlikte Türk askeri hakkındaki yorumlar1.

Murdoch metnin çok büyük bir kısmını ilk iki unsura ayırmıştır. Bu çerçevede İtilaf Devletleri'nin Çanakkale cephesini terk etmelerinde ve özellikle Anzak efsanesinin oluşmasında ciddi payı olduğunu kabul etmemiz gerekir. Başarısızlığın sorumlusu olarak gördügü İngiliz kurmay sınıfını tasvir ederken acınası, başarısız, niteliksiz gibi tabirler kullanan Murdoch, bu konuda birçok örnek üzerinden değerlendirme yapmaktadır. Mesela Ağustos ayının başında Suvla Koyu'nda gerçekleştirilen askeri operasyonları utanç verici diye nitelendirirken, hastalık ve susuzluk meselelerinde yine kurmay heyetinin çok ciddi hatalar yaptığından bahsetmektedir. İtilaf kuvvetleri için hezimetin en önemli sebebinin askerlerin hem komutanlarına hem Londra'ya artık güvenlerinin kalmaması olduğunu belirten Murdoch'ın asıl niyetinin Hamilton'1 değiştirmek olduğu anlaşılmaktadır. Nitekim bunu raporunun sonuna doğru yaptığı çarpıcı Enver Paşa benzetmesiyle ortaya koymaktadır. Yapılacak şeyin Enver Paşa'dan bile daha fazla nefret edilen Hamilton'ın ve kurmaylarının görevden alınması olduğunu belirten Murdoch kısa bir süre sonra bunun gerçekleştiğine de şahitlik etmiştir.

Murdoch'ın ikinci husus olarak üzerinde durduğu Anzak efsanesinin oluşmasındaki payı yadsınamaz. Metnin tamamında Anzak askerleriyle ilgili en küçük bir olumsuz yaklaşım sergilemediği gibi askerlere yönelik bitmek tükenmek bilmeyen enerjileri, şanlı askerlerimiz, kahramanlarımız gibi ifadeler kullanmakta, savaştaki başarılarda Anzakların büyük bir rolü olduğuna vurgu yapmaktadır. Avustralya başbakanına yönelik, bilmekten mutlu olacağınızı düşünüyorum, askerlerimiz kahramanca öldüler ifadesi Anzak efsanesinin temellerini atarken nasıl bir üslup kullandığını da göstermesi açısından dikkate değerdir. 
Murdoch'ın diğer iki hususa oranla raporu yazmaktaki amacı farklı olduğu için fazla bahsetmediği üçüncü unsur yukarıda da bahsedildiği üzere Türkler hakkındaki görüşleridir. Türk askeri hakkında metnin tamamında neredeyse tek bir olumsuz kelime kullanmayan Murdoch, birkaç yerde Türk askerinin cesur ve yüce gönüllü olduğundan bahsetmektedir. Onun bu konudaki yaklaşımını gösteren en net ifadesini raporun sonlarına doğru kaydettiğini görüyoruz. Türklerle ilgili ifade etmesi gereken önemli şeylerin başında onların gösterdiği insanlık ve cesaretin geldiğini söyleyen Murdoch, yine aynı yerde Türklerin birçok şekilde fevkalade düzeyde insanlık ve cesaret örneği gösterdiğinden bahsetmektedir. Sözün özü Murdoch raporunda böylelikle başka birçok kaynakta da teyit edilen Türk askerinin cesaret, insanlık ve vatan sevgisinin ne kadar güçlü olduğunu tarihe kayıt düşmektedir. 


\section{Kaynakça}

\section{Arşiv}

Sir Keith Arthur Murdoch (1885-1952) Gallipoli Letter from Keith Arthur Murdoch to Andrew Fisher 1915, Manuscripts Collection, MS 2823 Papers of Sir Keith Arthur Murdoch, 1908-1967. nla.msms2823-2.

\section{Telif Eserler ve Gazeteler}

Arango, Tim, "At Gallipoli, a Campaign That Laid Ground for National Identities" New York Times, 26.06.2014.

Aspinall-Oglander, C. F., Büyük Harbin Tarihi Çanakkale Gelibolu Askeri Harekâtı, Cilt 1-2, (haz. Metin Martı), İstanbul, Arma Yayınları, 2005.

Atabey, Figen, Çanakkale Muharebelerinin Deniz Cephesi, Türk Tarih Kurumu, Ankara 2014.

Bartlett, Ellis Ashmead, Çanakkale Gerçeği (Çev. Yüzbaşı Rahmi; Yay. Haz. Muzaffer Albayrak), Yeditepe Yay., İstanbul 2007.

Bartlett, Ellis Ashmead, The Uncensored Dardanelles, Hutchinson and Co. London 1928.

Beddie, B., "Pearce, Sir George Foster (1870-1952)", Australian Dictionary of Biography, volume. 11, (MUP), 1988.

Chronicle, "Funeral of Sir Keith Murdoch", 09.10.1952.

Delingpole, James, "Without Gallipoli, we'd have no Page 3", The Spectator, 2 May 2015.

Domergue, Gabriel, Çanakkale Yolunda, Çev. Ömer Faruk Turan, Babıali Kültür Yayıncılı̆̆ı, İstanbul 2007.

Fitzhardinge, L. F., "Hughes, William Morris (Billy) (1862-1952)", Australian Dictonary of Biography, volume. 9, (MUP), 1983.

Genelkurmay Harp Tarihi Başkanlığı, Birinci Dünya Harbi'nde Türk Harbi, Çanakkale Cephesi Harekâtı, V. Cilt, 1. Kitap, Genelkurmay Basımevi, Ankara 1993.

Göleç, Mustafa, "Amerikalı Bir Gazetecinin Gözüyle Çanakkale Deniz ve Kara Savaşları: George Abel Schreiner ve Çanakkale Günlükleri”, Çanakkale Araştırmaları Türk Yıllı $\breve{g}$, Y1l: 13, Bahar 2015, Say1 18, s. 593-635.

Hatip, S. Murat, "Birinci Dünya Harbi Çanakkale Savaşları'na Genel Bakış ve Az Bilinenler Çanakkale Savaşı Denizde mi Kazanıldı?”, Çanakkale Araştırmaları Türk Yıllı̆̆l, Yıı: 13, Bahar 2015, Say1: 18, s. 161-193

Independent, "Keith Murdoch: A new book examines Rupert Murdoch's father, Gallipoli, and the birth of the media dynasty", 20 October 2015.

İskefiyeli, Zeynep, "Savaş ve Propaganda: Resimli İngiliz Dergilerinde Çanakkale Cephesi”, Yeni Türkiye Çanakkale Özel Sayısı, Y11 21, Sayı 65, Ocak-Şubat 2015, s. 1461- 1473.

Karacakaya, Recep, “Çanakkale Savaşları’nın Amerikan Basınındaki Yansımaları”, Yeni Türkiye Çanakkale Özel Saylsı, Y1l 21, Say1 65, Ocak-Şubat 2015, s. 1357-1362.

Knightley, Phillip, The First Casualty - From Crimea to Vietnam: The War Correspondent as Hero, Propagandist, and Myth Maker, New York and London 1975.

Kuruloğlu, Fehim, “Sydney Morning Herald Gazetesi'ne Göre Gelibolu'da Savaş ve Barış, Peace and War in Gallipoli According to Sydney Morning Herald", III. International Gallipoli Symposium, 20-25 Nisan 2012, İstanbul 2013, s. 345-361.

Mcgregor, Jim and Gerry Docherty, "Gallipoli 18: Keith Murdoch And The Great Witch-Hunt", First World War Hidden History. 
Moorehead, Alan, Çanakkale Geçilmez, Çev. Güney Salman, Milliyet Yay., İstanbul 1972.

Murdoch, Keith, Gallipoli Letter, Allen \& Unvin, Australia 2010.

Özkaya, Yücel, “Türk ve Dünya Basınında Çanakkale Savaşları”, Atatürk Araştırma Merkezi Dergisi XII/34, Ankara 1996, s. 295-313.

Page, Bruce and Elaine Porter, The Murdoch Archipelago. London: Simon \& Schuster, 2003.

Pearlman, Jonathan, "How Rupert Murdoch's father changed the course of the Gallipoli campaign", The Telegraph, 24.04.2015.

Schweder, Paul, Çanakkale Cephesinde Türklerin Genel Karargahında, Çev. Eşref Bengi Özbilen, Yeditepe Yayınevi, İstanbul 2012.

Serle, Geoffrey, "Murdoch, Sir Keith Arthur (1885-1952)", Australian Dictionary of Biography, vol. 10, 1986, s. 622-627.

Sydney Morning Herald, "How one man's Report on Gallipoli Changed The Course of War", 18 November 1968 , s. 8.

The Age, "Sir Keith Murdoch Dies Suddenly", 06.10.1952.

The Telegraph, "How Rupert Murdoch's father changed the course of the Gallipoli campaign", 24.04.2015.

Zabel, Rudolf, İstanbul İçin Savaş Bir Alman Gazetecinin Çanakkale Savaşı Anıları, Çev. Rüstem Aslan, Cümle Yayınları, Ankara 2015.

Zwar, Desmond, In Search Of Keith Murdoch, London: Macmillan 1980.

\section{Internet Kaynakları}

http://aa.com.tr/tr/turkiye/yabanci-gazeteciler-canakkale-savaslarini-anlatti/58287 (11.03.2017).

http://adb.anu.edu.au/biography/hughes-william-morris-billy-6761 (12.04.2017)

http://adb.anu.edu.au/biography/pearce-sir-george-foster-7996 (12.04.2017).

http://trove.nla.gov.au/ndp/del/article/205423236? search Term=keith\%20 murdoch\&searchLimits $=.(15.07 .2017)$

http://www.firstworldwar.com/bio/milner.htm. (22.04.2017)

http://www.independent.co.uk/news/media/keith-murdoch-a-new-book-examines-rupertmurdochs-father-gallipoli-and-the-birth-of-the-media-a6701756.html (12.04.2017).

http://www.naa.gov.au/Images/Richardson_tcm16-35865.pdf. (25.05.2017).

https://firstworldwarhiddenhistory.wordpress.com/2015/04/22/gallipoli-18-keith-murdochand-the-great-witch-hunt/ (12.04. 2014).

https://www.spectator.co.uk/2015/05/without-gallipoli-wed-have-no-page-3-says-jamesdelingpole/\# (12. 04. 2017). 


\section{Ekler}

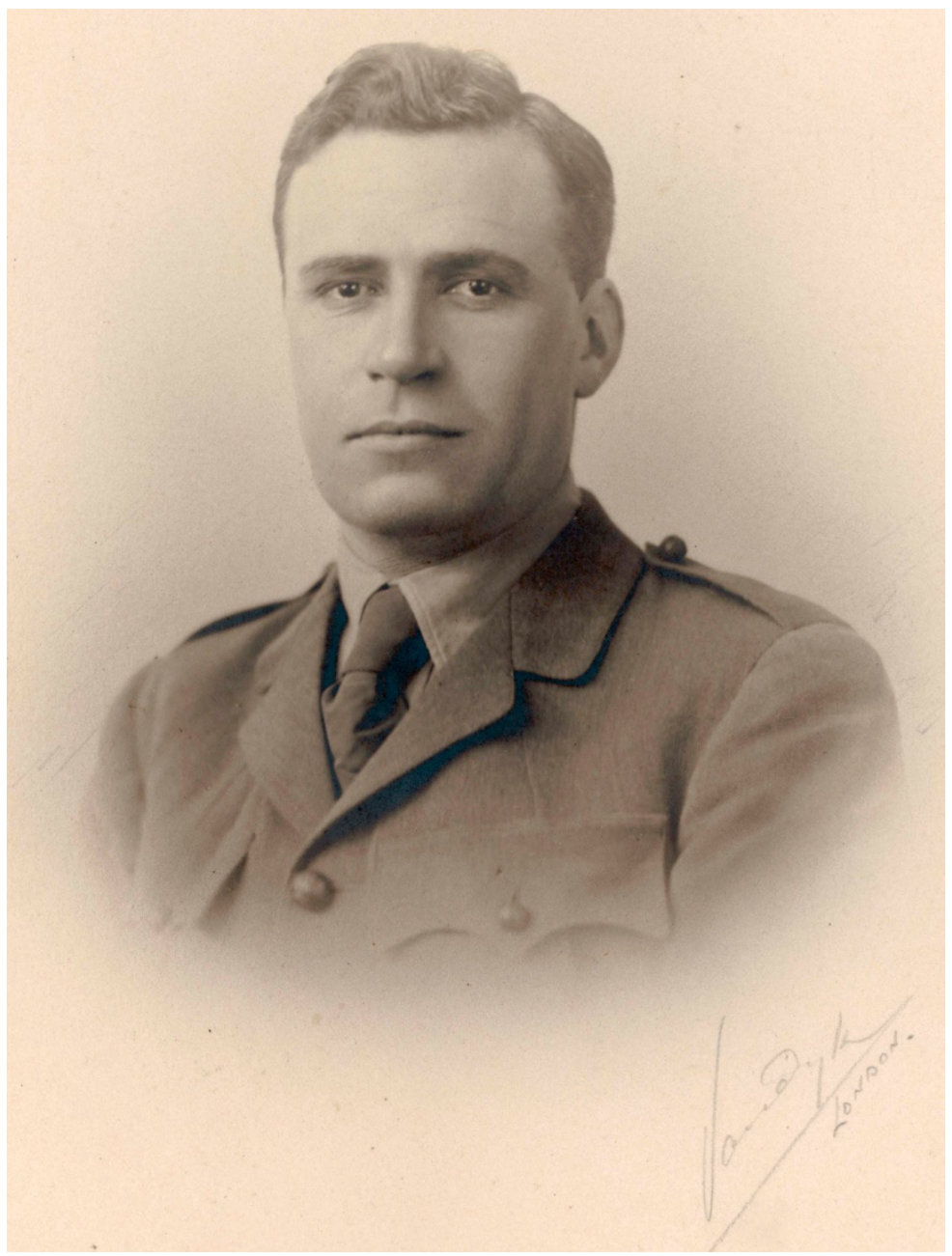

Ek 1: Keith Arthur Murdoch'1n Portresi

http://blogs.slv.vic.gov.au/our-stories/the-letter-that-changed-history/ (26.08.2017) 


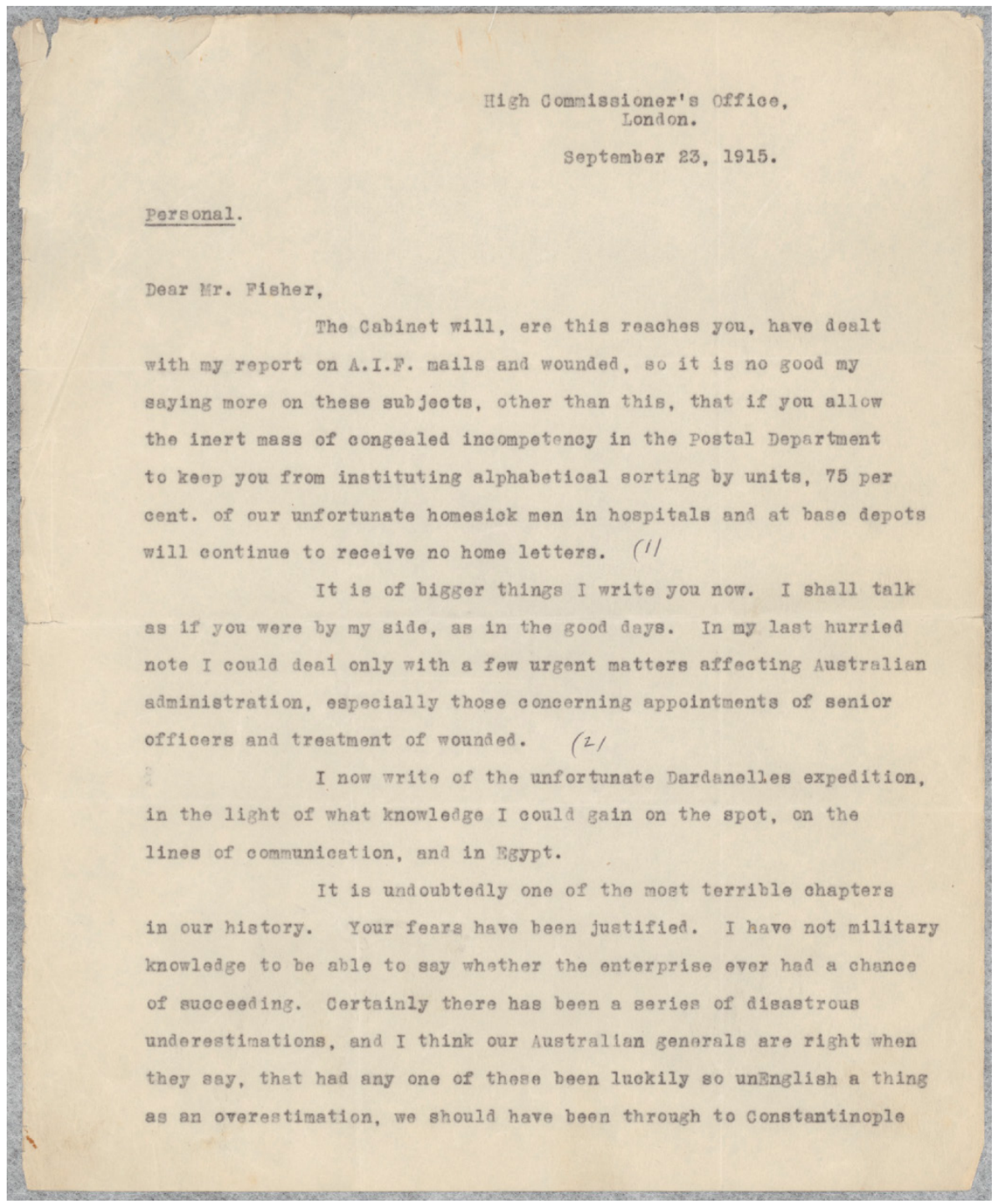

Ek 2. Murdoch'1n Raporunun İlk Sayfas1

Gallipoli Letter from Keith Arthur Murdoch to Andrew Fisher 1915, Manuscripts Collection, MS 2823 Papers of Sir Keith Arthur Murdoch, 1908-1967. nla.ms-ms2823-2. 